УДК 332.6

DOI: $10.33764 / 2687-041 X-2021-3-191-193$

\title{
ПРОБЛЕМЫ ОЦЕНКИ ЗЕМЕЛЬНОГО УЧАСТКА
}

\section{Никита Константинович Невелев}

Сибирский государственный университет геосистем и технологий, 630108, Россия, г. Новосибирск, ул. Плахотного, 10, обучающийся, тел. (383)361-01-09, e-mail: nshevelevv@mail.ru

\section{Елена Викторовна Убоженко}

Сибирский государственный университет геосистем и технологий, 630108, Россия, г. Новосибирск, ул. Плахотного, 10, кандидат экономических наук, доцент кафедры цифровой экономики и менеджмента, тел. (913)472-36-87, e-mail: ewunsk@yandex.ru

В статье произведен анализ проблем оценки земельных участков на современном этапе, предложены мероприятия для их устранения и повышения эффективности использования методик при рыночной и кадастровой оценке земель.

Ключевые слова: земельный участок, оценка, кадастр недвижимости, рыночная стоимость, кадастровая стоимость

\section{PROBLEMS OF LAND VALUATION}

\section{Nikita K. Shevelev}

Siberian State University of Geosystems and Technologies, 10, Plakhotnogo St., Novosibirsk, 630108, Russia, Student, Department of Cadastre and Territorial Planning, phone: (383)361-01-09, e-mail: nshevelevv@mail.ru

\section{Elena V. Ubozhenko}

Siberian State University of Geosystems and Technologies, 10, Plakhotnogo St., Novosibirsk, 630108, Russia, Ph. D., Head of the Department of Digital Economics and Management, phone: (913)472-36-87, e-mail: ewunsk@yandex.ru

The article analyzed the problems of assessing land plots at the present stage, proposed measures to eliminate them and increase the efficiency of using methods in market and cadastral land assessment.

Keywords: land, valuation, real estate cadastre, market value, cadastral value

Земля является основополагающим базисом процесса жизнедеятельности общества в целом - здесь задействованы все сферы общества, и соответственно важным является тот факт, чтобы оценка земельных участков была адекватной и справедливой в целях развития экономики и повышения ее функционирования [2].

Оценка стоимости земельного участка состоит из упорядоченного и целенаправленного процесса определения в денежном эквиваленте рыночной и кадастровой стоимости [1]. Сама цель оценки может быть связана с множеством разных задач - будущая продажа участка, коммерческое использование участка, использование под индивидуальные потребности и др. [3]. 
Помимо определения земельного налога кадастровая оценка земельного участка определяет также качественные параметры и условия, от которого будет зависеть стоимость участка, а также предполагает анализ ее структуры [4]. Опишем факторы, которые отрицательно влияют на качественный показатель оценки кадастровой стоимости:

- неправильный порядок нахождения кадастровой стоимости вновь образованных или раннее учтенных и измененных объектов;

- слабое урегулирование ситуации при отборе исполнителей кадастровых работ с учетом опыта и квалификации;

- расчет налога без соответствия значимости суммы для населения Российской Федерации и экономики в целом;

- отсутствие проверки со стороны Росреестра в части привлечения оценщика к ответственности при неверных результатах оценки;

- механизм кадастровой оценки земельных участков недоступен и закрыт для большей части населения государства;

- природные и климатические условия, а также другие особенности отдельных земельных участков не учитываются при проведении оценки.

В настоящее время рыночная стоимость земельных участков определяется посредством метода сравнения продаж с учетом того, что земельный рынок достаточно развит [5]. Для эффективного и рационального процесса проведения данной оценки нужна достоверная информация по рынку земельных участков, которые аналогичны оцениваемому объекту [6].

Основная проблема оценки земельных участков состоит в том, что множество факторов не учитывается в данном процессе, когда объекты оцениваются по основным характеристикам (в основном это сведения об участках из ЕГРН) [7]. Таким образом, один земельный участок с ровной поверхностью и хорошей почвой будет идентичен другому участку с травяными кочками и болотистостью, при этом их основные параметры аналогичны. Соответственно стоимость второго земельного участка будет больше, потому что ему придется потратить денежные средства на устранение проблем. Также стоит отметить, что в Российской Федерации пока что не сформировано полноценной и единой информационной базы по рыночной цене разных земельных участков, как, например, в кадастрах европейских стран, где содержатся данные с подробным описанием характеристик зданий и земель.

Для того, чтобы устранить описанные выше проблемные моменты, возникающие в кадастровой и рыночной оценке земельных участков, требуется провести ряд мероприятий.

Во-первых, необходимо пересмотреть методики оценки и утвердить новые, где будет возможность оспаривать кадастровый отчет еще до его утверждения.

Во-вторых, нужно учитывать социальные и экономические последствия после проведения процесса оценки.

В-третьих, необходимо создать систему «открытого» ценообразования земельных участков, которая смогла бы обеспечить прозрачность сделок. 
В-четвертых, требуется расширить перечень сведений по земельным участкам, которые содержатся в ЕГРН.

И в-пятых, разработать на законодательном уровне единую информационную базу земельных участков, которая будет отражать кадастровую стоимость и другие характеристики, необходимые для оценщика.

\section{БИБЛИОГРАФИЧЕСКИЙ СПИСОК}

1. Российская Федерация. Об оценочной стоимости в Российской Федерации [Электронный ресурс]: федер. закон от 29.07.1998 г. № 135-ФЗ. - Режим доступа : http://www.consultant.ru.

2. Варламов А. А., Комаров С. И. Оценка объектов недвижимости: учебник. - М.: Форум, 2015. $-217 \mathrm{c}$.

3. Варламов А. А. Земельный кадастр. В 6 томах. Том 5. Оценка земли и иной недвижимости / А. А. Варламов, А. В. Севостьянов. - М.: КолосС, 2015. - 72 с.

4. Жданова Р. В., Гвоздева О. В., Рассказова А. А. Практика оспаривания кадастровой стоимости земельных участков // Московский экономический журнал. - 2017. - № 1. - 24 с.

5. Корж А.Ю., Жданова Р.В. Актуальные вопросы об оспаривании кадастровой стоимости объектов недвижимости // Современные проблемы землепользования и кадастров: матер. 2-й международной межвузовской научно-практической конференции. - М., 2019. - 140-147 с.

6. Ширшикова Л. А., К вопросу о государственной кадастровой оценке земельных участков: недостатки и пути решения / Л.А. Ширшикова, Д.А. Ефанова // Молодой ученый. - 2015. №21. - 512-516 с. [Электронный ресурс]. - Режим доступа: https://moluch.ru/archive/101/22880/.

7. Шульцева С. М., Анализ увеличения количества споров о результатах определения кадастровой стоимости // Молодой ученый. 2019. - № 3. - 307 с.

(C) Н. К. Шевелев, Е. В. Убоженко, 2021 